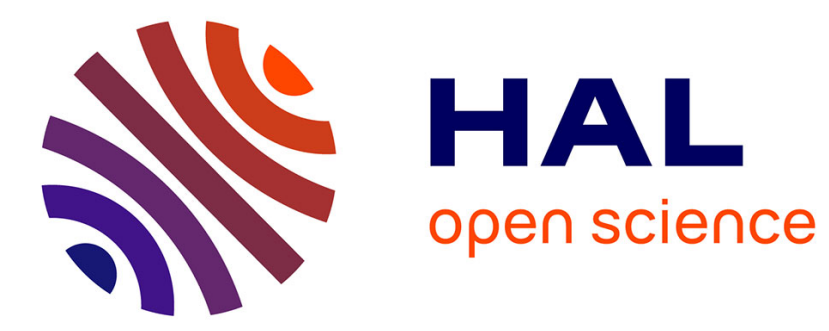

\title{
Structural study and phase transition investigation in a simple synthesis of porous architected- $\mathrm{ZnO}$ nanopowder
}

\author{
Congcong Shang, Antoine Barnabé
}

\section{To cite this version:}

Congcong Shang, Antoine Barnabé. Structural study and phase transition investigation in a simple synthesis of porous architected-ZnO nanopowder. Materials Characterization, 2013, vol. 86, pp. 206-211. 10.1016/j.matchar.2013.10.004 . hal-01167288

\section{HAL Id: hal-01167288 \\ https://hal.science/hal-01167288}

Submitted on 24 Jun 2015

HAL is a multi-disciplinary open access archive for the deposit and dissemination of scientific research documents, whether they are published or not. The documents may come from teaching and research institutions in France or abroad, or from public or private research centers.
L'archive ouverte pluridisciplinaire HAL, est destinée au dépôt et à la diffusion de documents scientifiques de niveau recherche, publiés ou non, émanant des établissements d'enseignement et de recherche français ou étrangers, des laboratoires publics ou privés. 


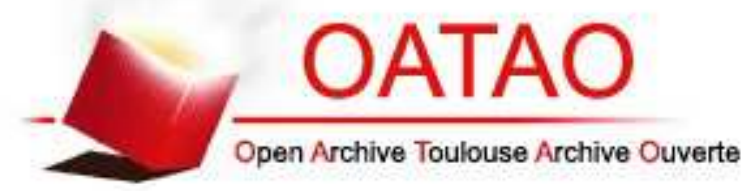

\section{Open Archive TOULOUSE Archive Ouverte (OATAO)}

OATAO is an open access repository that collects the work of Toulouse researchers and makes it freely available over the web where possible.

This is an author-deposited version published in : http://oatao.univ-toulouse.fr/ Eprints ID : 14008

To link to this article : doi: 10.1016/j.matchar.2013.10.004

URL : http://dx.doi.org/10.1016/j.matchar.2013.10.004

To cite this version : Shang, Congcong and Barnabé, Antoine Structural study and phase transition investigation in a simple synthesis of porous architected-ZnO nanopowder. (2013) Materials Characterization, vol. 86. pp. 206-211. ISSN 1044-5803

Any correspondance concerning this service should be sent to the repository administrator: staff-oatao@ listes-diff.inp-toulouse.fr 


\title{
Structural study and phase transition investigation in a simple synthesis of porous architected-ZnO nanopowder
}

\author{
C. Shang ${ }^{1}$, A. Barnabét, \\ CIRIMAT — UMR CNRS 5085 Institut Carnot, Université Paul Sabatier Toulouse III, 118 route de Narbonne, 31062 Toulouse Cedex 4, France
}

Keywords:

Oxides

Nanostructures

Chemical synthesis

Crystal structure

Phase equilibria

\begin{abstract}
A B S T R A C T
In this work, zinc oxide powder with a rectangular-shaped porous architecture, made of numerous spherical nanometric particles, was obtained. A simple precipitation/decomposition procedure was used comprising a zinc oxalate intermediate, obtained from zinc sulfate and oxalic acid without any additives. Detailed studies on zinc oxalate dehydration, decomposition and zinc oxide formation, were carried out using in-situ temperature X-ray diffraction and thermogravimetric analysis. During the investigation, the temperature dependence of particle sizes, lattice parameters and crystal structures of $\mathrm{ZnC}_{2} \mathrm{O}_{4} \cdot 2 \mathrm{H}_{2} \mathrm{O}, \mathrm{ZnC}_{2} \mathrm{O}_{4}$ and $\mathrm{ZnO}$ nanopowders were analyzed from room temperature to $450{ }^{\circ} \mathrm{C}$. Structural transitions were also discussed. The structure and morphology of the as-prepared $\mathrm{ZnO}$ nanopowder were investigated by electron microscopy and compared to the crystalline rectangular shape of $\mathrm{ZnC}_{2} \mathrm{O}_{4} \cdot 2 \mathrm{H}_{2} \mathrm{O}$. The calcination temperature, counter ion and precipitate agent were found to be related to the product's shape and diameter. Spherical $\mathrm{ZnO}$ nanoparticles with diameters of less than $20 \mathrm{~nm}$ and a maximum specific surface of $53 \mathrm{~m}^{2} / \mathrm{g}$ were obtained using this method.
\end{abstract}

\section{Introduction}

Zinc oxide $(\mathrm{ZnO})$ has been attracting a lot of attention for its various applications, such as semi-conductor devices, photo catalysts, pigments in paints and photovoltaic uses [1-6]. The well-known properties, such as the wide direct band-gap (3.3 eV), large exciton binding energy (60 meV), low cost, environmental friendly and abundance, make it a very interesting material. For different applications, $\mathrm{ZnO}$ can be used in various forms and morphologies [7-13]. Syntheses of powdered form ZnO using wet chemistry methods have already been widely reported [14-20]. There are a lot of parameters during synthesis that can affect the structure and microstructure of $\mathrm{ZnO}$ which are essential for their performance [17-19]. Thermal decomposition of zinc oxalate has been reported to produce porous and relatively high specific surface $\mathrm{ZnO}$ [6] which is especially interesting for gas sensing, photovoltaic or photocatalysis applications $[21,22,12]$. In the particular case of dye sensitized solar cells (DSSC), ZnO was reported as a good alternative of the conventional $\mathrm{TiO}_{2}$ semiconductor material for the first time in 1994 [23]. Since then, a lot of works focused on the development of new DSSC nanostructured photo-anodes made of $\mathrm{ZnO}$ porous nanostructures with various morphologies (nanowire, nanosheet, branchednanostructure of multi-layers material, nanowire-nanoparticle composite, ...) have been reported $[24,9,25-27]$ reaching an overall DSSC efficiency for more than 7\% [28].

In the present work, the precipitation of $\mathrm{ZnC}_{2} \mathrm{O}_{4}$-based precursor in hydro-alcoholic medium was carried out first, followed by in-situ high temperature X-ray diffraction analysis of the precursor from 50 to $450^{\circ} \mathrm{C}$. Detailed structural and

\footnotetext{
* Corresponding author. Tel.: +33 5615577 51; fax: +33 561556163 .

E-mail address: barnabe@chimie.ups-tlse.fr (A. Barnabé).

${ }^{1}$ Country of origin: China.

2 Country of origin: France.
} 
micro-structural studies were performed for each of the crystalline structures obtained. Finally, ZnO nanopowder with porous architecture was prepared through the obtention and thermal decomposition of zinc oxalate di-hydrate and anhydrous intermediates.

\section{Experimental}

\subsection{Material Preparation}

All the chemicals were of analytical purity grade and used as received. The raw materials used were $\mathrm{H}_{2} \mathrm{C}_{2} \mathrm{O}_{4} \cdot 2 \mathrm{H}_{2} \mathrm{O}$ and $\mathrm{ZnSO}_{4} \cdot 7 \mathrm{H}_{2} \mathrm{O}$ as sources of oxalate and zinc respectively. A solution of $0.02 \mathrm{~mol}$ of oxalic acid in a mixture of $192 \mathrm{ml}$ of ethanol and $64 \mathrm{ml}$ of water, was added dropwise into $128 \mathrm{ml}$ of an equimolar solution of zinc salt in distilled water. After stirring for $1 \mathrm{~h}$ at room temperature, a white precipitate was obtained and separated by centrifugation and washed several times with distilled water by centrifugation again. This precipitate was dried at $80^{\circ} \mathrm{C}$ for several hours to attain the $\mathrm{ZnC}_{2} \mathrm{O}_{4} \cdot 2 \mathrm{H}_{2} \mathrm{O}$ powder precursor. A detailed study of the thermal behavior of $\mathrm{ZnC}_{2} \mathrm{O}_{4} \cdot 2 \mathrm{H}_{2} \mathrm{O}$ was performed up to $450{ }^{\circ} \mathrm{C}$, which is a temperature compromise in DSSC application between obtaining good electronic contacts and maintaining high porosity while respecting the conducting glass support stability [29]. Finally, the characteristics of the zinc oxide obtained were investigated after cooling down to room temperature.

\subsection{Material Characterization}

The structural and microstructural studies of the precursors and products were carried out using the following equipments and techniques. One point Brunauer-Emmett-Teller (BET) measurement was obtained with $\mathrm{N}_{2}$ as absorption gas at $77 \mathrm{~K}$ by using a Micromeritics FlowSorb II 2300 apparatus. Microstructural images were produced from scanning electron microscopy (SEM) using a Field Emission Gun SEM JEOL JEM 6700F. Conventional and temperature dependent powder $\mathrm{X}$-ray diffraction (XRD) analyses were performed by using
Bruker D4 Endeavor and D8 Advance diffractometers respectively, both equipped with a 1D LynxEye detector (Cu K $\alpha$ ). For temperature dependent XRD, the sample was heated in an Anton Paar HTK $1200 \mathrm{~N}$ heating chamber with a $30^{\circ} \mathrm{C} / \mathrm{min}$ heating rate. XRD patterns were recorded every $25^{\circ} \mathrm{C}$ from room temperature to $450 \mathrm{C}^{\circ}$ with a $20 \mathrm{~min}$ counting time. Rietveld refinements of the XRD patterns were performed using the FullProf/Win PlotR software package, in which the background was estimated by linear interpolation, and the peak shape was modeled by a pseudo-Voigt function. The observed profile parameters extracted from the Rietveld analysis $\left(\mathrm{FWHM}^{\mathrm{obs}}\right)$, coupled with the instrumental broadening ( FWHM $^{\text {instr }}$ ) determined from a standard reference material $\left(\alpha-\mathrm{Al}_{2} \mathrm{O}_{3}\right)$, were used to calculate the mean crystallite apparent size $(\varepsilon)$, by applying the Williamson-Hall plot $\left(\left(F_{W H M^{\text {obs }}}-\mathrm{FWHM}^{\text {instr }}\right) \cos \theta=\mathrm{f}(\sin \theta)\right)$ [30]. Thermogravimetric analysis (TGA) was performed with a SETARAM DT-TGA 92B thermo-balance under air atmosphere with a heating rate of $3{ }^{\circ} \mathrm{C} / \mathrm{min}$.

\section{Results and Discussion}

Fig. 1 shows the successive characteristic evolution of the XRD patterns $\left(2 \theta\right.$ from $17.5^{\circ}$ to $40^{\circ}$ ) recorded upon heating, from 50 to $450{ }^{\circ} \mathrm{C}$ for every increment of $25^{\circ} \mathrm{C}$, during the decomposition of the oxalate precursor. The corresponding TGA plot of this precursor is shown in Fig. 2. Both TGA and XRD analyses show that the zinc oxalate dihydrate precursor $\left(\mathrm{ZnC}_{2} \mathrm{O}_{4} \cdot 2 \mathrm{H}_{2} \mathrm{O}\right)$ decomposes first to anhydrous zinc oxalate $\left(\mathrm{ZnC}_{2} \mathrm{O}_{4}\right)$ at $\sim 125^{\circ} \mathrm{C}$ and then to zinc oxide $(\mathrm{ZnO})$ at $\sim 355^{\circ} \mathrm{C}$ according to the following reactions:

$\mathrm{ZnC}_{2} \mathrm{O}_{4} \cdot 2 \mathrm{H}_{2} \mathrm{O}(\mathrm{s}) \rightarrow \mathrm{ZnC}_{2} \mathrm{O}_{4}(\mathrm{~s})+2 \mathrm{H}_{2} \mathrm{O}(\mathrm{g})$

$\mathrm{ZnC}_{2} \mathrm{O}_{4}(\mathrm{~s}) \rightarrow \mathrm{ZnO}(\mathrm{s})+\mathrm{CO}_{2}(\mathrm{~g})+\mathrm{CO}(\mathrm{g})$.

The two experimental TGA weight losses of $18.5 \%$ and $37.8 \%$ correspond closely to the calculated values $(19.0 \%$ and $38.0 \%$ ) based on reactions (1) and (2).

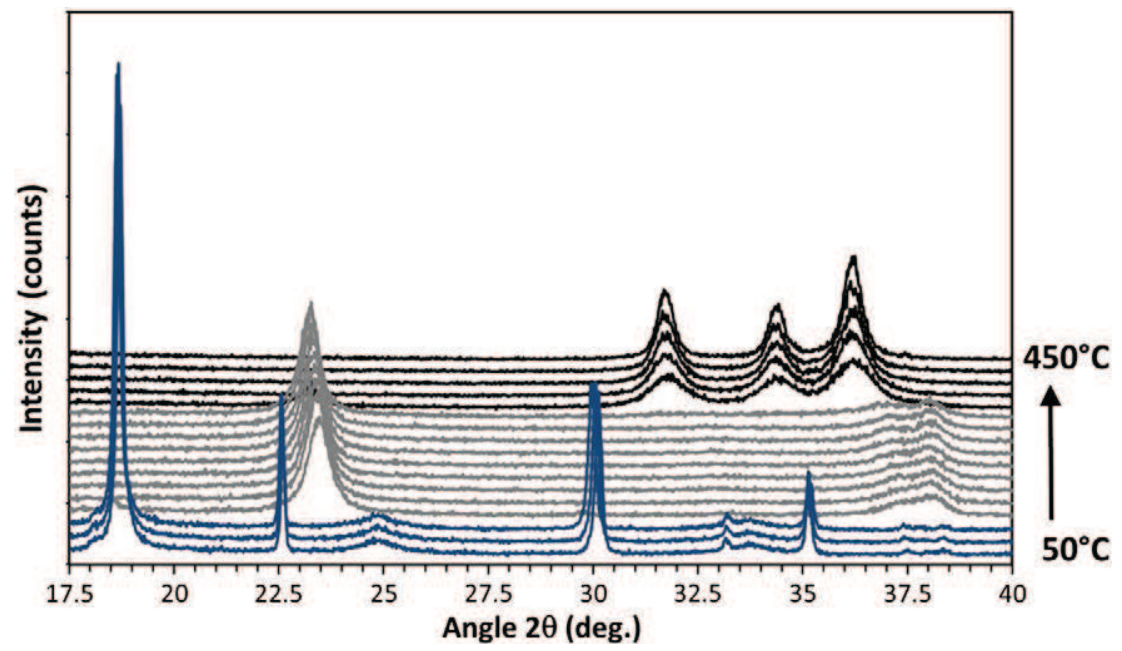

Fig. 1 - Temperature XRD patterns in the 50 to $450{ }^{\circ} \mathrm{C}$ temperature range for zinc oxalate precursor. 


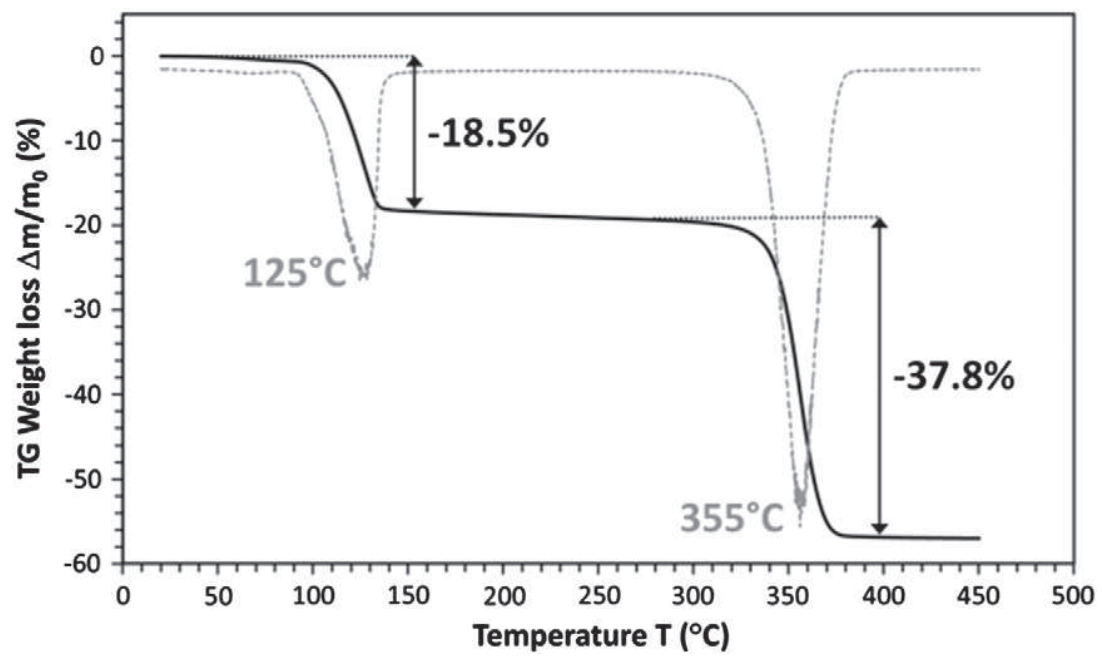

Fig. 2 - TGA/DTG curves in the 50 to $450{ }^{\circ} \mathrm{C}$ temperature range for zinc oxalate precursor.

\subsection{Zinc Oxalate Dihydrate $\left(\mathrm{ZnC}_{2} \mathrm{O}_{4} \cdot 2 \mathrm{H}_{2} \mathrm{O}\right)$}

At room temperature, the oxalate precursor which was directly obtained after precipitation corresponds to the pure metastable orthorhombic $\beta$ form of the zinc oxalate dihydrate ( $\beta$ $\mathrm{ZnC}_{2} \mathrm{O}_{4} \cdot 2 \mathrm{H}_{2} \mathrm{O}$ ). As no doublet peak located at $2 \theta / \lambda_{\mathrm{CuK} \alpha} \sim 18.74^{\circ}$ is clearly visible, there is no particular reason to index the XRD pattern according to the monoclinic $\alpha$ form (humboldtine). This result is in good agreement with previous reports of metal oxalate dihydrate synthesized in a hydro-alcoholic solution $[31,32]$. The refined cell parameters determined for this zinc oxalate dihydrate phase in orthorhombic $\mathrm{Cccm}$ space group are reported in Table $1\left(a_{0}, b_{0}\right.$ and $\left.c_{0}\right)$ at 50,75 and $100{ }^{\circ} \mathrm{C}$. In this temperature range, the cell parameters are almost constant, the calculated X-ray density is equal to $\rho=2.50 \mathrm{~g} / \mathrm{cm}^{3}$ and the mean crystallite size is approximately $\varepsilon \sim 100 \mathrm{~nm}$. In the structure that is represented in a 3D perspective view in Fig. 3a, the zinc cation is six-folded coordinated: four oxygen anions that belong to the oxalate groups form $-\mathrm{C}_{2} \mathrm{O}_{4}-\mathrm{Zn}-\mathrm{C}_{2} \mathrm{O}_{4}-\mathrm{Zn}$ - chains along the $b_{\mathrm{o}}$ axis and two apical oxygen anions that belong to the water molecules located along the $a_{\mathrm{o}}$ axis.

\subsection{Zinc Oxalate Anhydrous $\left(\mathrm{ZnC}_{2} \mathrm{O}_{4}\right)$}

At $125^{\circ} \mathrm{C}$, the dehydration induces a structure reconfiguration toward anhydrous zinc oxalate $\mathrm{ZnC}_{2} \mathrm{O}_{4}$, isostructural with $\beta-\mathrm{MC}_{2} \mathrm{O}_{4}$ where $\mathrm{M}=\{\mathrm{Fe}, \mathrm{Co}, \mathrm{Ni}, \mathrm{Zn}, \mathrm{Cu}, \ldots\}$ [33]. The refined cell parameters in monoclinic $P 2_{1} / n$ space group $\left(a_{m}, b_{m}, c_{m}\right.$ and $\left.\beta\right)$

Table 1 - Refined unit cell parameters, X-ray densities and mean crystallite apparent sizes of $\mathrm{ZnC}_{2} \mathrm{O}_{4} \cdot 2 \mathrm{H}_{2} \mathrm{O}$, $\mathrm{ZnC} \mathrm{O}_{4}$ and $\mathrm{ZnO}$ materials in the 50 to $450{ }^{\circ} \mathrm{C}$ temperature range.

\begin{tabular}{|c|c|c|c|c|c|c|c|c|c|}
\hline $\begin{array}{c}\mathrm{T} \\
\left({ }^{\circ} \mathrm{C}\right)\end{array}$ & Compound & Space group & $\begin{array}{c}\mathrm{a} \\
(\AA)\end{array}$ & $\begin{array}{c}b \\
(\AA)\end{array}$ & $\begin{array}{c}c \\
(\AA)\end{array}$ & $\begin{array}{l}\beta \\
\left(^{\circ}\right)\end{array}$ & $\begin{array}{c}\mathrm{V} \\
\left(\AA^{3}\right)\end{array}$ & $\begin{array}{c}\rho \\
\left(\mathrm{g} / \mathrm{cm}^{3}\right)\end{array}$ & $\begin{array}{c}\varepsilon \\
(\mathrm{nm})\end{array}$ \\
\hline 50 & $\mathrm{ZnC}_{2} \mathrm{O}_{4} \cdot 2 \mathrm{H}_{2} \mathrm{O}$ & C ccm & $11.863(3)$ & $5.395(1)$ & $15.718(5)$ & & $1006.5(8)$ & $2.500(2)$ & 120 \\
\hline 75 & $\mathrm{ZnC}_{2} \mathrm{O}_{4} \cdot 2 \mathrm{H}_{2} \mathrm{O}$ & C ccm & $11.875(2)$ & $5.3910(7)$ & $15.720(4)$ & & $1006.8(6)$ & $2.499(2)$ & 115 \\
\hline 100 & $\mathrm{ZnC}_{2} \mathrm{O}_{4} \cdot 2 \mathrm{H}_{2} \mathrm{O}$ & C ccm & $11.910(2)$ & $5.3886(8)$ & $15.734(4)$ & & $1009.9(6)$ & $2.492(2)$ & 110 \\
\hline 125 & $\mathrm{ZnC}_{2} \mathrm{O}_{4}$ & P $21 / n$ & $6.042(5)$ & $5.24(1)$ & $5.253(4)$ & $116.0(1)$ & $149.5(7)$ & $3.41(2)$ & 15 \\
\hline 150 & $\mathrm{ZnC}_{2} \mathrm{O}_{4}$ & P $2{ }_{1} / \mathrm{n}$ & $6.025(9)$ & $5.28(1)$ & $5.255(4)$ & $115.60(7)$ & $151.2(6)$ & $3.37(1)$ & 17 \\
\hline 175 & $\mathrm{ZnC}_{2} \mathrm{O}_{4}$ & P $2{ }_{1} / \mathrm{n}$ & $6.013(5)$ & $5.297(6)$ & $5.246(3)$ & $115.20(4)$ & $151.3(4)$ & $3.37(1)$ & 17 \\
\hline 200 & $\mathrm{ZnC}_{2} \mathrm{O}_{4}$ & P $21 / n$ & $6.014(6)$ & $5.302(7)$ & $5.245(3)$ & $115.13(4)$ & $151.4(4)$ & $3.36(1)$ & 16 \\
\hline 225 & $\mathrm{ZnC}_{2} \mathrm{O}_{4}$ & P $2{ }_{1} / \mathrm{n}$ & $6.016(6)$ & $5.294(7)$ & $5.241(3)$ & $115.21(4)$ & $150.9(4)$ & $3.37(1)$ & 17 \\
\hline 250 & $\mathrm{ZnC}_{2} \mathrm{O}_{4}$ & P $2{ }_{1} / \mathrm{n}$ & $6.024(6)$ & $5.319(7)$ & $5.245(3)$ & $115.18(4)$ & $151.9(4)$ & $3.35(1)$ & 17 \\
\hline 275 & $\mathrm{ZnC}_{2} \mathrm{O}_{4}$ & P $21 / n$ & $6.030(6)$ & $5.313(7)$ & $5.237(3)$ & $115.23(5)$ & $151.2(4)$ & 3.37 (1) & 17 \\
\hline 300 & $\mathrm{ZnC}_{2} \mathrm{O}_{4}$ & P $2{ }_{1} / \mathrm{n}$ & $6.040(6)$ & $5.329(6)$ & $5.242(3)$ & $115.19(4)$ & $152.2(4)$ & 3.35 (1) & 18 \\
\hline 325 & $\mathrm{ZnC}_{2} \mathrm{O}_{4}$ & P $2{ }_{1} / \mathrm{n}$ & $6.051(6)$ & 5.337 (8) & 5.249 (3) & $115.13(4)$ & $153.3(5)$ & $3.32(1)$ & 18 \\
\hline 350 & $\mathrm{ZnO}$ & $\mathrm{P}_{3} / \mathrm{mmc}$ & $3.253(9)$ & & $5.22(1)$ & & $47.8(4)$ & $5.65(5)$ & 10 \\
\hline 375 & $\mathrm{ZnO}$ & $\mathrm{P} 6_{3} / \mathrm{mmc}$ & 3.257 (5) & & $5.223(7)$ & & $48.0(2)$ & $5.63(3)$ & 12 \\
\hline 400 & $\mathrm{ZnO}$ & $\mathrm{P} 6_{3} / \mathrm{mmc}$ & 3.259 (4) & & $5.217(6)$ & & $47.9(2)$ & $5.64(2)$ & 15 \\
\hline 425 & $\mathrm{ZnO}$ & $\mathrm{P} \sigma_{3} / \mathrm{mmc}$ & 3.259 (4) & & $5.222(6)$ & & $48.0(2)$ & $5.63(2)$ & 19 \\
\hline 450 & $\mathrm{ZnO}$ & $\mathrm{P} 6_{3} / \mathrm{mmc}$ & $3.260(4)$ & & $5.223(6)$ & & $48.1(2)$ & $5.62(2)$ & 20 \\
\hline 50 & $\mathrm{ZnO}$ & $\mathrm{P} \sigma_{3} / \mathrm{mmc}$ & $3.250(3)$ & & $5.209(5)$ & & $47.6(1)$ & $5.67(2)$ & 20 \\
\hline 50 & $\mathrm{ZnO}$ & $\mathrm{P} 6_{3} / \mathrm{mmc}$ & $3.250(3)$ & & $5.209(5)$ & & $47.6(1)$ & $5.67(2)$ & 20 \\
\hline 450 & $\mathrm{ZnO}$ & $\mathrm{P} \sigma_{3} / \mathrm{mmc}$ & 3.260 (3) & & $5.222(4)$ & & $48.0(2)$ & $5.62(2)$ & 22 \\
\hline 50 & $\mathrm{ZnO}$ & $\mathrm{P} 6_{3} / \mathrm{mmc}$ & $3.250(3)$ & & $5.209(4)$ & & $47.6(2)$ & $5.67(2)$ & 22 \\
\hline
\end{tabular}



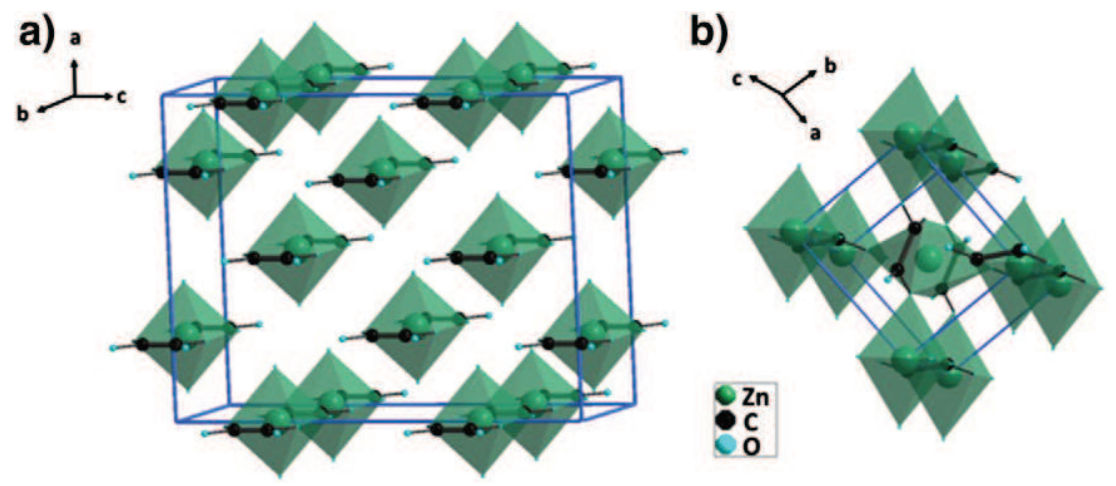

Fig. 3 - Schematic representations in perspective $3 \mathrm{D}$ view of the a) $\mathrm{ZnC}_{2} \mathrm{O}_{4} \cdot 2 \mathrm{H}_{2} \mathrm{O}$ and b) $\mathrm{ZnC}_{2} \mathrm{O}_{4}$ zinc oxalates structures.

are listed in Table 1. In this structure, every zinc atom is surrounded by six oxygen atoms, forming highly distorted octahedra which are connected to one another through corners. These six oxygen atoms all belong to oxalate groups. The first four oxygen anions are located at two similar distances from the central zinc atom $\left(\mathrm{d}(\mathrm{Zn}-\mathrm{O})_{1}=1.98 \AA\right.$ and $\mathrm{d}(\mathrm{Zn}-\mathrm{O})_{1^{\prime}}=$ $2.01 \AA$ at $\left.125^{\circ} \mathrm{C}\right)$. They all form $-\mathrm{C}_{2} \mathrm{O}_{4}-\mathrm{Zn}-\mathrm{C}_{2} \mathrm{O}_{4}-\mathrm{Zn}$ - chains along the $c_{m}$ axis (Fig. $\left.3 b\right)$. These chains with $\mathrm{d}(\mathrm{Zn}-\mathrm{Zn})=c_{m}=$ 5.253(4) $\AA$ in $\mathrm{ZnC}_{2} \mathrm{O}_{4}$ at $125^{\circ} \mathrm{C}$, correspond to the chains that already exist in $\mathrm{ZnC}_{2} \mathrm{O}_{4} \cdot 2 \mathrm{H}_{2} \mathrm{O}$, with slightly lower zinc to zinc distances $\left(\mathrm{d}(\mathrm{Zn}-\mathrm{Zn})=b_{0}=5.3886(8) \AA\right.$ in $\mathrm{ZnC}_{2} \mathrm{O}_{4} \cdot 2 \mathrm{H}_{2} \mathrm{O}$ at $100^{\circ} \mathrm{C}$ ), due to the disappearance of the weak hydrogen bonds. The dehydration simultaneously induces a tilt of the $-\mathrm{C}_{2} \mathrm{O}_{4}-\mathrm{Zn}-\mathrm{C}_{2} \mathrm{O}_{4}-\mathrm{Zn}$ - chains located at $\mathrm{x}=1 / 4$ around the $b_{0}$ axis of the $\mathrm{ZnC}_{2} \mathrm{O}_{4} \cdot 2 \mathrm{H}_{2} \mathrm{O}$ structure. This allows one to complete the coordination of the distorted $\mathrm{ZnO}_{6}$ octahedron in the anhydrous structure, with the two last oxygen anions located at $\mathrm{d}(\mathrm{Zn}-\mathrm{O})_{2}=2.36 \AA$. These two sets of $\mathrm{d}(\mathrm{Zn}-\mathrm{O})$ are confirmed in Raman spectroscopy by characteristics peaks located at 228 and $267 \mathrm{~cm}^{-1}$ (Fig. 4), which are attributed to metal-oxygen stretching vibrations and are in good agreement with previous reports [34].

In the 125 to $325^{\circ} \mathrm{C}$ temperature range, $a_{m}$ and $c_{m}$ parameters are quite stable $\left(+0.16\right.$ and $-0.08 \%$ respectively), whereas the $b_{m}$ parameter significantly increases $(+1.79 \%)$. The calculated X-ray density then decreases from $\rho=3.41 \mathrm{~g} / \mathrm{cm}^{3}$ to $\rho=3.32 \mathrm{~g} / \mathrm{cm}^{3}$ in this temperature range. The mean crystallite size is stable at

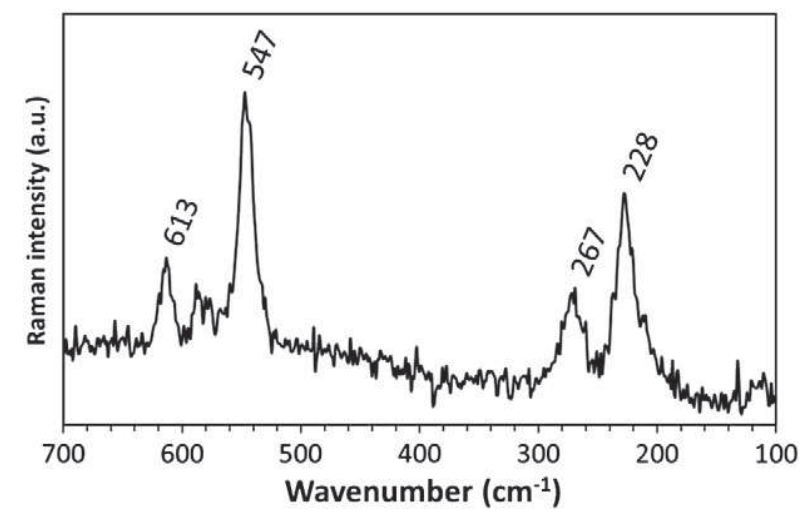

Fig. 4 - Raman spectra of the $100-700 \mathrm{~cm}^{-1}$ region of $\mathrm{ZnC}_{2} \mathrm{O}_{4}$. $15<\varepsilon<20 \mathrm{~nm}$. The anisotropy of the thermal dilatation leads to an increase in the distortion of the $\mathrm{ZnO}_{6}$ octahedron. The $\mathrm{Zn}$ to $\mathrm{O}$ bond length $\left(\mathrm{d}(\mathrm{Zn}-\mathrm{O})_{2}\right)$, which was already large in comparison to the theoretical value $\left(\mathrm{d}\left(\mathrm{Zn}^{2+} \mathrm{vI}^{-} \mathrm{O}\right) \mathrm{th}=2.14 \AA[35]\right)$, continues to increase and tends to weaken the $\mathrm{Zn}-\mathrm{O}$ bond strength. At $\mathrm{T} \sim 350^{\circ} \mathrm{C}$, the structure is unstable and hence the process of structure-reconfiguration consists of the following sequence of consecutive bond breaking: the two longest $\mathrm{Zn}-\mathrm{O}$ bonds, the four other $\mathrm{Zn}-\mathrm{O}$ bonds, then the $\mathrm{C}-\mathrm{C}$ bonds which results to the generation of a free $\mathrm{CO}_{2}$ molecule. This pattern is in accordance with first principle calculations, performed by Kolezynski et al. [36], of band structure, density of states, electron density topology, bond orders and valences.

\subsection{Zinc Oxide ( $\mathrm{ZnO})$}

Above $350^{\circ} \mathrm{C}$, pure zinc oxide with a wurtzite structure is obtained. In this structure, the zinc atoms are in tetrahedral coordination. The refined cell parameters in hexagonal $\mathrm{P} \sigma_{3} / \mathrm{mmc}$ space group $\left(a_{h}\right.$ and $\left.c_{h}\right)$ are listed in Table 1 . From $350^{\circ} \mathrm{C}$ to $400{ }^{\circ} \mathrm{C}$, as shown in Table 1 , the lattice parameters vary rapidly due to the process of structure reconfiguration from the anhydrous oxalate structure to $\mathrm{ZnO}$. Above $400{ }^{\circ} \mathrm{C}, a_{h}$ and $c_{h}$ converge to reproducible values obtained for $\mathrm{ZnO}$ upon further cooling and heating treatments with $a_{h}=3.260(4) \AA$ and $c_{h}=5.223(6) \AA$ at $\mathrm{T}=450^{\circ} \mathrm{C}$. The calculated thermal expansion coefficients $\alpha_{\mathrm{a}}=$ $7.710^{-6} \mathrm{~K}^{-1}$ and $\alpha_{\mathrm{c}}=6.710^{-6} \mathrm{~K}^{-1}$ in the RT- $450^{\circ} \mathrm{C}$ temperature range defined by $\alpha_{\mathrm{a}}=(1 / \mathrm{a})(\mathrm{da} / \mathrm{dT})$ or $\alpha_{\mathrm{c}}=(1 / \mathrm{c})(\mathrm{dc} / \mathrm{dT})$ and the ratio, $c_{h} / a_{h}=1.60$, at $450{ }^{\circ} \mathrm{C}$ are in good accordance with literature values [37]. In the $350-450{ }^{\circ} \mathrm{C}$ temperature range, while $350^{\circ} \mathrm{C}$ is the lowest temperature at which $\mathrm{ZnO}$ could be obtained, the mean crystallite size increases from $\varepsilon=10 \mathrm{~nm}$ to $\varepsilon=20 \mathrm{~nm}$ with no crystallite shape anisotropy as previously reported by Audebrand et al. [38].

At room temperature, the lattice parameters of the soobtained ZnO material are $a_{h}=3.2503(2) \AA$ and $c_{h}=5.2091(3) \AA$ with a calculated X-ray density of $\rho=5.67 \mathrm{~g} / \mathrm{cm}^{3}$ (Table 1). The corresponding SEM images with those of the $\mathrm{ZnC}_{2} \mathrm{O}_{4} \cdot 2 \mathrm{H}_{2} \mathrm{O}$ precursor are presented in Fig. 5. The $\mathrm{ZnO}$ porous architecture, confined in a sub-micronic rectangular shape (Fig. 5b), consists of a large number of homogeneous nanometric spherical zinc oxide particles (Fig. 5c). Its specific surface, $\mathrm{S}_{\mathrm{BET}}=34 \mathrm{~m}^{2} / \mathrm{g}$, corresponds to an estimated particle size of $\mathrm{D}_{\mathrm{BET}}=31 \mathrm{~nm}$ defined by $\mathrm{D}_{\mathrm{BET}}=$ $6 \times 10^{4} / \rho \times \mathrm{S}_{\mathrm{BET}}$ with $\rho=5.67 \mathrm{~g} / \mathrm{cm}^{3}$ (Table 1). This particle size is 

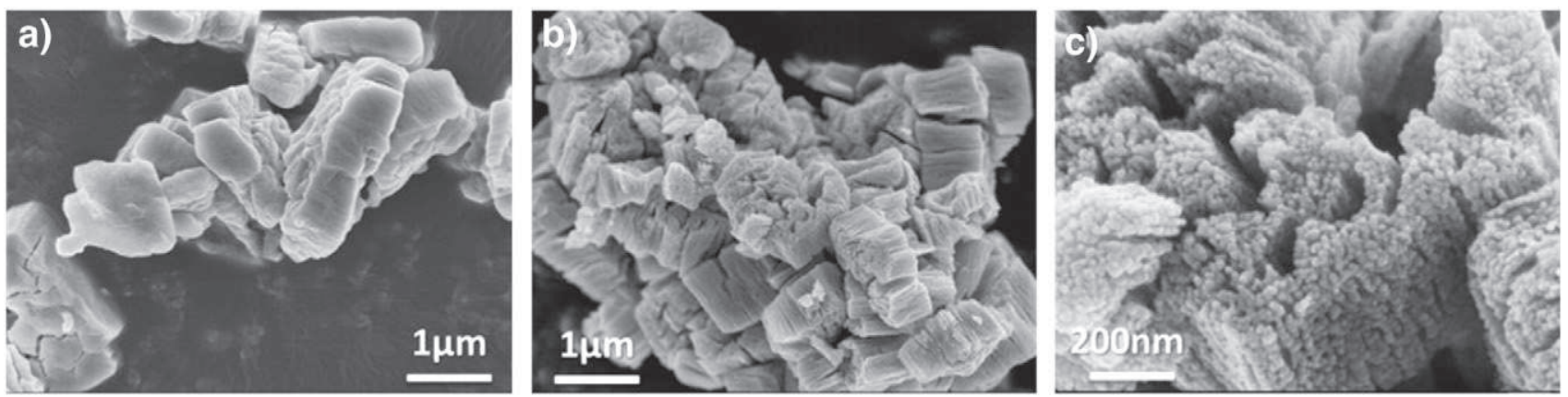

Fig. 5 - SEM micrographs of a) $\mathrm{ZnC}_{2} \mathrm{O}_{4}{ }_{2} \mathrm{H}_{2} \mathrm{O}$, b) $\mathrm{ZnC}_{2} \mathrm{O}_{4}$ and c) $\mathrm{Zn}_{\mathrm{O}}$.

consistent with XRD and SEM measurements with $\mathrm{D}_{\mathrm{XRD}}=27 \mathrm{~nm}$ $\left(D_{\mathrm{XRD}}=4 / 3 \varepsilon\right.$ because the particles are spherical) and $D_{\mathrm{SEM}}=$ 20-40 nm respectively.

The particle size of the $\mathrm{ZnO}$ nanopowder in this porous architecture is temperature dependent due to the merging of the smaller particles into larger ones through solid state diffusion [39]. For ZnO prepared by the same process but decomposed only at $350^{\circ} \mathrm{C}$, the particle size is approximately $50 \%$ smaller than that of $450^{\circ} \mathrm{C}$ with $\mathrm{D}_{\mathrm{BET}}=20 \mathrm{~nm}\left(\mathrm{~S}_{\mathrm{BET}}=\right.$ $53 \mathrm{~m}^{2} / \mathrm{g}$ ) and $D_{\mathrm{XRD}}=13 \mathrm{~nm}$, whereas at $500^{\circ} \mathrm{C}$, the particle size increases up to $\mathrm{D}_{\mathrm{XRD}}=48 \mathrm{~nm}$. The particle size of the $\mathrm{ZnO}$ nanopowder in this porous architecture is also counter ion dependent. With the same synthesizing process by using nitrate $\left(\mathrm{Zn}\left(\mathrm{NO}_{3}\right)_{2}\right)$ instead of sulfate as the zinc source. The $\mathrm{ZnO}$ particle size obtained at $450{ }^{\circ} \mathrm{C}$ is $\mathrm{D}_{\mathrm{BET}}=71 \mathrm{~nm}$, i.e. twice of that from the $\mathrm{ZnSO}_{4}$ precursor. This has also been corroborated by Raj et al., in which $\mathrm{ZnO}$ nanopowder with similar architecture but larger crystalline and particle sizes were obtained from zinc chloride salt and oxalic acid at $500{ }^{\circ} \mathrm{C}$.

This porous $\mathrm{ZnO}$ architecture is precursor dependent as demonstrated by the SEM in Fig. 5a. The micrograph of the oxalate precursor exhibits an identical rectangular shape. During the calcination process, the initial pore in the precursor is formed by the release of the two water molecules (Reaction (1)). Hence, the pore volume further increased for $\mathrm{T} \geq 350{ }^{\circ} \mathrm{C}$ with the subsequent release of $\mathrm{CO}_{2}$ and $\mathrm{CO}$ from the precursor (Reaction (2)), the simultaneous nucleation and growth of $\mathrm{ZnO}$ primary particles. This is in good agreement with the work of Jia et al. [11].

\section{Conclusion}

ZnO nanopowders with porous architecture were synthesized by a simple and inexpensive method. This method consists of 1) precipitation of metastable orthorhombic zinc oxalate dihydrate $\left(\beta-\mathrm{ZnC}_{2} \mathrm{O}_{4} \cdot 2 \mathrm{H}_{2} \mathrm{O}\right)$ in a hydro alcoholic solution from zinc salt and oxalic acid at room temperature, 2 ) its dehydration into monoclinic anhydrous zinc oxalate $\left(\beta-\mathrm{ZnC}_{2} \mathrm{O}_{4}\right)$ at $125^{\circ} \mathrm{C}$ and 3) decomposition into zinc oxide nanopowder at $350^{\circ} \mathrm{C}$. Detailed crystalline parameters for each of the species were analyzed and the phase transition mechanisms between different structures were shown in detail by high temperature XRD coupled with TGA analysis in the temperature range of RT $-450{ }^{\circ} \mathrm{C}$. From the $\mathrm{XRD}, \mathrm{SEM}$ and BET analysis, it was confirmed that the resultant
ZnO porous architecture consists of a large number of homogeneous nanometric spherical zinc oxide particles with a pure hexagonal wurtzite structure, confined in a sub-micronic rectangular shape. The particle size of the $\mathrm{ZnO}$ nanopowder has been proven to be temperature and counter ion dependent. In this synthesis, $\sim 13$ to $20 \mathrm{~nm}$ spherical $\mathrm{ZnO}$ particles with a $53 \mathrm{~m}^{2} / \mathrm{g}$ specific surface could be easily obtained, rendering it a very interesting candidate as a photo catalyst and for photovoltaic application.

\section{Acknowledgments}

The equipment support for temperature XRD from Fédération de Recherche FERMAT is gratefully appreciated. CS thanks the PRES-Région Midi-Pyrénées for the financial support.

\section{R E F E R E N C E S}

[1] Pan Z, Dai Z, Wang Z. Nanobelts of semiconducting oxides. Science 2001;291:1947-9.

[2] Ozgur U, Alivov Y, Liu C, Teke A, Reshchikov M, Dogan S, et al. A comprehensive review of $\mathrm{ZnO}$ materials and devices. J Appl Phys 2005;98 [041301/1-041301/103].

[3] Li G-R, Dawa C-R, Lu X-H, Yu X-L, Tong Y-X. Use of additives in the electrodeposition of nanostructured Eu3+/ZnO films for photoluminescent devices. Langmuir 2009;25:2378-84.

[4] Yang Y, Du G, Xin X, Xu B. Hierarchical ZnO microrods: synthesis, structure, optical and photocatalytic properties. Appl Phys A Mater Sci Process 2011;104:1229-35.

[5] Sivalingam Y, Martinelli E, Catini A, Magna G, Pomarico G, Basoli F, et al. Gas-sensitive photoconductivity of porphyrin-functionalized $\mathrm{ZnO}$ nanorods. J Phys Chem C 2012;116:9151-7.

[6] Cho S, Jang J-W, Park HJ, Jung D-W, Jung A, Lee JS, et al. A method for synthesizing ZnO-carbonaceous species nanocomposites, and their conversion to quasi-single crystal mesoporous ZnO nanostructures. RSC Adv 2012;2:566-72.

[7] Lee D-K, Bang J, Park M, Lee J-H, Yang H. Organic acid-based wet etching behaviors of $\mathrm{Ga}$-doped $\mathrm{ZnO}$ films sputter-deposited at different substrate temperatures. Thin Solid Films 2010;518:4046-51.

[8] Jimenez-Cadena G, Comini E, Ferroni M, Vomiero A, Sberveglieri G. Synthesis of different $\mathrm{ZnO}$ nanostructures by modified PVD process and potential use for dye-sensitized solar cells. Mater Chem Phys 2010;124:694-8. 
[9] Umar A, Al-Hajry A, Hahn YB, Kim DH. Rapid synthesis and dye-sensitized solar cell applications of hexagonal-shaped ZnO nanorods. Electrochim Acta 2009;54:5358-62.

[10] Ke L, Bin Dolmanan S, Shen L, Pallathadk PK, Zhang Z, Lai DMY, et al. Degradation mechanism of ZnO-based dye-sensitized solar cells. Sol Energy Mater Sol Cells 2010;94:323-6.

[11] Jia Z, Ren D, Xu L, Zhu R. Preparation, characterization and photocatalytic activity of porous zinc oxide superstructure. Mater Sci Semicond Process 2012;15:270-6.

[12] Xie D, Chang L, Wang F, Du G, Xu B. Ultrasound-assisted synthesis of macro-/mesoporous $\mathrm{ZnO}$ double-pyramids and their optical and photocatalytic properties. J Alloys Compd 2012:176-81.

[13] Zheng J, Jiang Z-Y, Kuang Q Xie Z-X, Huang R-B, Zheng L-S. Shape-controlled fabrication of porous $\mathrm{ZnO}$ architectures and their photocatalytic properties. J Solid State Chem 2009;182:115-21.

[14] Dhage S, Pasricha R, Ravi V. Synthesis of fine particles of $\mathrm{ZnO}$ at 100 degrees C. Mater Lett 2005;59:779-81.

[15] Ahmad T, Vaidya S, Sarkar N, Ghosh S, Ganguli A. Zinc oxalate nanorods: a convenient precursor to uniform nanoparticles of ZnO. Nanotechnology 2006;17:1236-40.

[16] Hu QR, Wang SL, Tang WH. Effects of alkali on the morphologies and photoluminescence properties of $\mathrm{ZnO}$ nanostructures. Mater Lett 2010;64:1822-4.

[17] Music S, Dragcevia D, Popovic S, Ivanda M. Precipitation of $\mathrm{ZnO}$ particles and their properties. Mater Lett 2005;59:2388-93.

[18] Zhu YF, Zhou GH, Ding HY, Liu AH, Lin YB, Li NL. Controllable synthesis of hierarchical $\mathrm{ZnO}$ nanostructures via a chemical route. Phys E 2010;42:2460-5.

[19] Hui Z, Yang D, Li S, Ma X, Ji Y, Xu J, et al. Controllable growth of $\mathrm{ZnO}$ nanostructures by citric acid assisted hydrothermal process. Mater Lett 2005;59:1696-700.

[20] Zareie M, Gholami A, Bahrami M, Rezaei AH, Keshavarz MH. A simple method for preparation of micro-sized ZnO flakes. Mater Lett 2013;91:255-7.

[21] Gupta SK, Joshi A, Kaur M. Development of gas sensors using ZnO nanostructures. J Chem Sci 2010;122:57-62.

[22] Dittrich T, Belaidi A, Ennaoui A. Concepts of inorganic solid-state nanostructured solar cells. Sol Energy Mater Sol Cells 2011;95:1527-36.

[23] Redmond G, Fitzmaurice D, Graetzel M. Visible light sensitization by cis-bis (thiocyanato) bis (2, 2'-bipyridyl-4, $4^{\prime}$-dicarboxylato) ruthenium (II) of a transparent nanocrystalline $\mathrm{ZnO}$ film prepared by sol-gel techniques. Chem Mater 1994;6:686-91.

[24] Jimenez-Cadena G, Comini E, Ferroni M, Vomiero A, Sberveglieri G. Synthesis of different $\mathrm{ZnO}$ nanostructures by modified PVD process and potential use for dye-sensitized solar cells. Mater Chem Phys 2010;124:694-8.

[25] Mou J, Zhang W, Fan J, Deng H, Chen W. Facile synthesis of $\mathrm{ZnO}$ nanobullets/nanoflakes and their applications to dye-sensitized solar cells. J Alloys Compd 2011;509:961-5.

[26] Lu L, Li R, Fan K, Peng T. Effects of annealing conditions on the photoelectrochemical properties of dye-sensitized solar cells made with ZnO nanoparticles. Sol Energy 2010;84:844-53.

[27] Lee CH, Chiu WH, Lee KM, Yen WH, Lin HF, Hsieh WF, et al. The influence of tetrapod-like $\mathrm{ZnO}$ morphology and electrolytes on energy conversion efficiency of dye-sensitized solar cells. Electrochim Acta 2010;55:8422-9.

[28] Chen LY, Yin YT. Hierarchically assembled ZnO nanoparticles on high diffusion coefficient $\mathrm{ZnO}$ nanowire arrays for high efficiency dye-sensitized solar cells. Nanoscale 2013;5:1777-80.

[29] Hagfeldt A, Gratzel M. Chem Rev 1995;95:49-68.

[30] Langford J, Louer D. Powder diffraction. Rep Prog Phys 1996:59:131-234.

[31] Lopez MC, Tirado JL, Perez Vicente C. Structural and comparative electrochemical study of $\mathrm{M}$ (II) oxalates, $\mathrm{M}=\mathrm{Mn}$, $\mathrm{Fe}$, Co, Ni, Cu, Zn. J Power Sources 2013;227:65-71.

[32] Kanade K, Kale B, Aiyer R, Das B. Effect of solvents on the synthesis of nano-size zinc oxide and its properties. Mater Res Bull 2006;41:590-600.

[33] Kondrashev Y, Bogdanov V, Golubev S, Pron G. Crystal structure of the ordered phase of zinc oxalate and the structure of anhydrous $\mathrm{Fe}^{2+}, \mathrm{Co}^{2+}, \mathrm{Ni}^{2+}, \mathrm{Cu}^{2+}$ oxalates. J Struct Chem 1985;26:74-7.

[34] Raj CJ, Joshi RK, Varma KBR. Synthesis from zinc oxalate, growth mechanism and optical properties of $\mathrm{ZnO}$ nano/micro structures. Cryst Res Technol 2011;46:1181-8.

[35] Shannon R. Revised effective ionic radii and systematic studies of interatomic distances in halides and chalcogenides. Acta Crystallogr A 1976;32:751-67.

[36] Kolezynski A, Malecki A. First principles studies of thermal decomposition of anhydrous zinc oxalate. J Therm Anal Calorim 2009;96:645-51.

[37] Iwanaga H, Kunishige A, Takeuchi S. Anisotropic thermal expansion in wurtzite-type crystals. J Mater Sci 2000;35:2451-4.

[38] Audebrand N, Auffrédic J-P, Louër D. X-ray diffraction study of the early stages of the growth of nanoscale zinc oxide crystallites obtained from thermal decomposition of four precursors. General concepts on precursor-dependent microstructural properties. Chem Mater 1998;10:2450-61.

[39] Singh P, Kumar A, Kaushal A, Kaur D, Pandey A, Goyal RN. In situ high temperature XRD studies of $\mathrm{ZnO}$ nanopowder prepared via cost effective ultrasonic mist chemical vapour deposition. Bull Mater Sci 2008;31:573-7. 